\section{A point sampling approach to woodlot analysis}

\section{J. D. MACARTHUR and D. W. ALGAR}

Department of Woodlot Management

Faculty of Agriculture

McGill University

Macdonald College, P.Q.

Lack of interest in woodlot management is often a result of the owner's inability to visualize his problems and possibilities. If data on woodlots can be made available in a form that provides a basis for planned action, interest is likely to be stimulated and intelligent action may follow. This paper describes a method of woodlot analysis designed to obtain information needed for planning and to present it in an easily understood format.

Since 1969 the Department of Woodlot Management at Macdonald College has been engaged in a co-operative project, the Huntingdon Woodlot Study ${ }^{1}$, with private owners in Huntingdon County in Quebec. Essentially the project involves the study of woodlots and the development of management plans designed to meet their owners' objectives.

Estimates needed as a basis for planning must be obtained quickly and cheaply. To achieve this an application of point sampling has been used. The method, based on established point sampling principles (Grosenbaugh 1952) is simple, rapid, and relatively inexpensive. It removes some of the obstacles to rapid woodlot analysis as a guide to management planning or to obtain rough estimates of value for property or stumpage sales without excessive cost.

Forest conditions encountered in this project cover a wide range. Hardwood, mixedwood, softwood, old growth, second growth, pioneer stands and old sugar bushes are some examples. Condition also varies all the way from carefully tended to heavily overcut or neglected. Owner objectives similarly range from total preservation to total utilization, including total neglect through lack of interest or ignorance. Because of these features, and also because of certain methods of recording and summarizing data that have been used, a description of an approach to the problem will be of interest. It is assumed that the reader is familiar with the wedge prism method of point sampling.

\section{Methods}

General. a/ Stands in the woodlot to be studied are first delineated on aerial photographs. At this stage each stand is examined to plan field sampling tentatively. Areas of stands are not measured until after photo interpretation has been checked in the field.

1 The project is supported by a Quebec ARDA administration research grant and is under the direction of Professor A. R. C. Jones, Department of Woodlot Management, Faculty of Agriculture, Macdonald College, P.Q. b/ Each stand is visited and enough point samUne méthode d'inventaire par point d'échantillonnage appliquée à l'analyse des boisés de ferme. Ce travail décrit une application de la méthode d'inventaire par point d'échantillonnage dans le but d'obtenir des évaluations acceptables de l'information de base requise pour l'aménagement des boisés. Des données d'échantillonnage sont fournies dans le but d'illustrer l'utilisation des feuilles de pointage et les calculs nécessaires pour obtenir les estimés. La méthode est simple, rapide, relativement peu cồteuse, flexible et elle peut être adoptée à une variété de circonstances. On présente des analyses qui se rapprochent d'un modèle de peuplement et qui fournissent de l'excellent matériel pour présenter, discuter et envisager diverses décisions de gestion.

ples (usually 3 to 7 ) are taken to obtain bases for the estimates desired. An adequate number of samples is assumed to have been reached when a running average of basal area per acre levels off. Data are recorded on specially designed field sheets for office calculation of the various per acre estimates desired.

Field work is a matter of minutes per stand, most of the time being spent walking from sample point to sample point. Practical experience has been that half a day to a day is required in woodlots of 40 to 200 acres.

Equipment is inexpensive. Aerial photographs, maps, pocket stereoscope, hand compass, and a 10 -factor $(B A F=10)$ wedge prism are the basic tools. An increment borer and some inexpensive type of hypsometer such as a biltmore stick could be added if desired.

c/ Estimates of volume per acre are calculated using formulae developed by Grosenbaugh (1952) and Wilson and Robbins (1969) and are recorded in a format designed for the Huntingdon project where different alternatives are to be considered.

\begin{tabular}{|ll|}
\hline \multicolumn{2}{|c|}{ Abbreviations } \\
BA & basal area \\
BAF & basal area factor \\
b.f. & board feet \\
D & dimension stock \\
DBH & diameter breast height \\
F & fuelwood size trees \\
HF & height factor \\
L & sawlog size trees \\
LL & log-length category \\
N & number of sample points \\
P & pulpwood size trees \\
Pi & pickets \\
Po & posts \\
S & sawlog stock \\
TC & tree count \\
TTC & total tree count \\
V & veneer stock \\
\hline
\end{tabular}

Recording field data. The simplest sample would be a total tree count (TTC) to estimate gross basal area per acre. However, in our work, data are recorded by species, product class, and log class. Log quality may also be indicated if desired. 
A sample field record appears in Table 1 and illustrates the design of the tally sheet and procedure.

TABLE 1. Field record format and data for a stand where four species are present and two sample points were taken
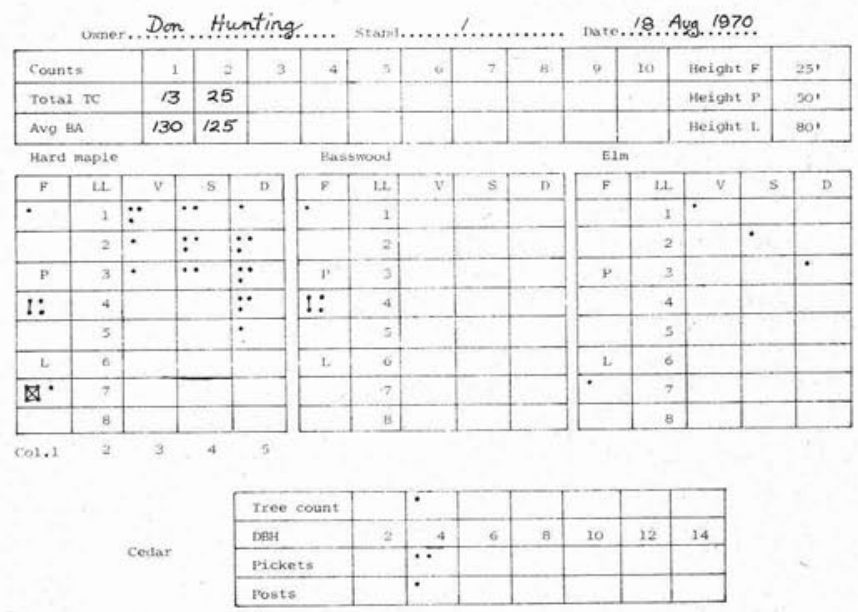

For a given stand each block in the tally sheet is used to record one species, with a cumulative dot tally being made as sample points are added. The total cumulative tree count for all species is recorded at the top of the sheet after each prism sweep and from it average basal area is readily obtained as sampling progresses.

The columns in the hard maple block in Table 1 (upper left) have been numbered at the bottom of the block to facilitate explanation. Column 1 is the total hard maple tree count for two sample points recorded by fuelwood, pulpwood, and sawlog sizes. In column 5 all eleven sawlog trees appear as dimension stock by the 8-foot log-length categories shown in Column 2. Seven of these trees are re-recorded in Column 4 as containing sawlogs, and five reappear in Column 3 as veneer producers. Minimum small-end log diameter is 8 inches for dimension stock, 10 inches for sawlogs, and 12 inches for veneer. Logs must also be of the appropriate quality class.

Only when there are sawlog tallies in Column 1 will tallies appear in Columns 3,4 , or 5 . In making this record each tree is tallied in all the appropriate places as it is counted - during the prism sweep. Tree heights are measured, or estimated, to the nearest five feet and log lengths and $\mathrm{DBH}$ are estimated.

At the bottom of the field tally sheet a special record of cedar trees containing pickets and posts is made. Trees counted are recorded in the top row above their $\mathrm{DBH}$ and the numbers of pickets and posts in each are recorded below as shown. In practice, field tally sheets have nine blocks and can account for nine species plus cedar.

Calculation of estimates. Tree counts are converted to the final estimates using appropriate formulae and conversion tables. As they are calculated, estimates are entered in the stand summary (Table 6 ). Estimates for hard maple based on the Table 1 tallies are worked out to illustrate the following items.
1/ The estimate of rough cords per acre is calculated by the formula:

$$
\text { Cords per acre }=\text { TTC } \times \text { HF } / \mathrm{N}
$$

with the HF being obtained from Table 2, which gives $\mathrm{HF}$ values for $\mathrm{BAF}=10$ calculated from the general formula:

Rough cords per acre $=\frac{\text { TTC } \times \text { BAF } \times \text { avg tree ht }}{10 \times 20 \times \mathrm{N}}$

Thus, for hard maple, the calculation is:

$\mathrm{F}(25 \mathrm{ft})$ Cords per acre $=$

$P(50 \mathrm{ft})$

$\mathrm{L}(80 \mathrm{ft})$

$1 \times 1.25 / 2=0.6$

$5 \times 2.50 / 2=6.2$

$11 \times 4.00 / 2=22.0$

Total cords per acre

28.8

2/ Estimates of board feet per acre are calculated using conversion factors given by Grosenbaugh (1952) for the International $1 / 4$-inch log rule. Factors for 16-foot logs were plotted and 8-foot log factors were read from the graph (Table 3 ).

Board feet per acre $=$ Total b.f. recorded / $\mathrm{N}$

To obtain board feet recorded, the number of trees in each log-length class is multiplied by the corresponding board-foot content (Table 3 ) and the products summed.

For hard maple, again, the calculation is given in Table 5.

TABLE 2. Tree heights in feet and corresponding height factors. BAF $=10$

Tree height

Height factor

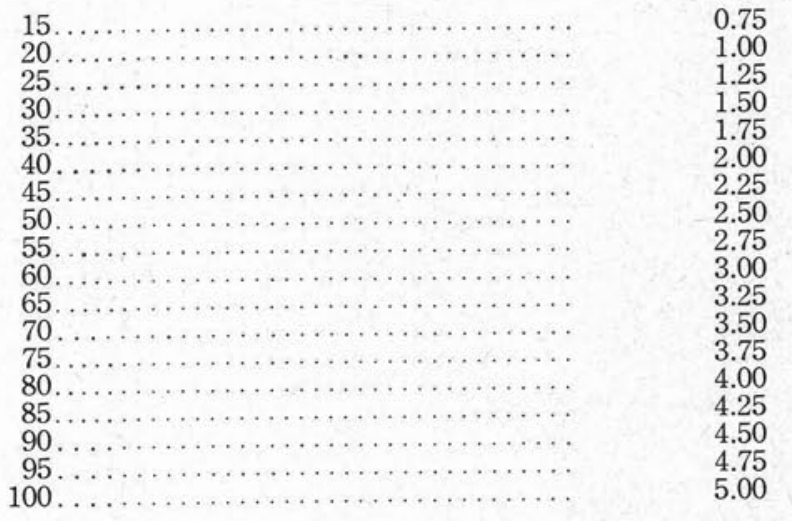

TABLE 3. Board foot content corresponding to 8-foot log length categories, $\mathrm{BAF}=10$

\begin{tabular}{|c|c|c|}
\hline $\begin{array}{l}\text { Number of } \\
\text { 8-foot logs }\end{array}$ & & $\begin{array}{c}\text { Board foot } \\
\text { content }\end{array}$ \\
\hline $\begin{array}{l}1 \\
2 \\
3 \\
4 \\
5 \\
6 \\
7 \\
8\end{array}$ & 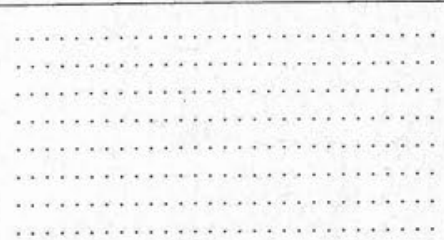 & $\begin{array}{r}350 \\
700 \\
1000 \\
1300 \\
1550 \\
1800 \\
2050 \\
2300\end{array}$ \\
\hline
\end{tabular}


The same calculations of cords and board feet are made for each species in the stand and the estimates are entered in the stand summary (Table $6)$.

3 / Where cedar is present, pickets and posts are estimated using the formula:

Pieces per acre $=$ Pieces recorded $/ \mathrm{N}$

where the value for pieces recorded is obtained from Table 4 (which was constructed using the formula: Pieces per acre $=$ Pieces counted $\times 10 /$ BA of DBH class).

In stand 1, two cedar pickets and one post were recorded in the 4-inch DBH class, so:

Pickets per acre $=230 / 2=115$

and posts per acre $=115 / 2=57$

TABLE 4. Pieces per acre (pickets and posts)

\begin{tabular}{crrrrrrr}
$\begin{array}{c}\text { Pieces } \\
\text { counted }\end{array}$ & $\mathbf{2}$ & $\mathbf{4}$ & $\mathbf{6}$ & $\mathbf{8}$ & $\mathbf{1 0}$ & $\mathbf{1 2}$ & $\mathbf{1 4}$ \\
& & & & & & & \\
1 & 454 & 115 & 51 & 29 & 18 & 13 & 9 \\
2 & 909 & 230 & 102 & 57 & 37 & 25 & 19 \\
3 & 1364 & 345 & 153 & 86 & 55 & 38 & 28 \\
4 & 1818 & 460 & 204 & 115 & 73 & 51 & 37 \\
5 & 2273 & 575 & 255 & 143 & 92 & 64 & 47 \\
6 & 2727 & 690 & 306 & 172 & 110 & 76 & 56 \\
7 & 3182 & 806 & 357 & 201 & 128 & 89 & 65 \\
8 & 3636 & 919 & 408 & 229 & 147 & 102 & 75 \\
9 & 4091 & 1034 & 459 & 258 & 165 & 115 & 84 \\
10 & 4545 & 1149 & 510 & 287 & 183 & 127 & 93 \\
\hline
\end{tabular}

TABLE 5. Calculation of board feet in hard maple example

\begin{tabular}{|c|}
\hline $\begin{array}{l}\text { Number of } \\
8-\mathrm{ft} \operatorname{logs}\end{array}$ \\
\hline
\end{tabular}

Dimension stock

\begin{tabular}{lrrr}
1 & 350 & 1 & 350 \\
2 & 700 & 3 & 2.100 \\
3 & 1,000 & 3 & 3,000 \\
4 & 1.300 & 3 & 3,900 \\
5 & 1,550 & 1 & 1,550 \\
\hline & & & 10,900
\end{tabular}

$\therefore$ b.f. per acre $=10,900 / 2=5,450$

10.900

Sawlogs

\begin{tabular}{rrrr}
1 & 350 & 2 & 700 \\
2 & 700 & 3 & 2.100 \\
3 & 1,000 & 2 & 2,000 \\
\hline & & & 4,800
\end{tabular}

Veneer logs

\begin{tabular}{crrr} 
logs & 350 & 3 & 1,050 \\
2 & 700 & 1 & 700 \\
3 & 1,000 & 1 & 1,000 \\
\cline { 3 - 4 } & & & 2,750
\end{tabular}

$\therefore$ b.f. per acre $=2,750 / 2=1.375$

\section{Results}

The calculated per acre estimates of cords, board feet, pickets and posts are entered in the summary (Table 6), a format designed to facilitate vizualization of the stand.

The whole stand is included under cords with volumes broken down by species and product class and totals shown for each one. Under board feet logs only are given. Total board feet are shown
TABLE 6. Final summary format and data for Stand 1. Per acre estimates by species, tree class, and log quality

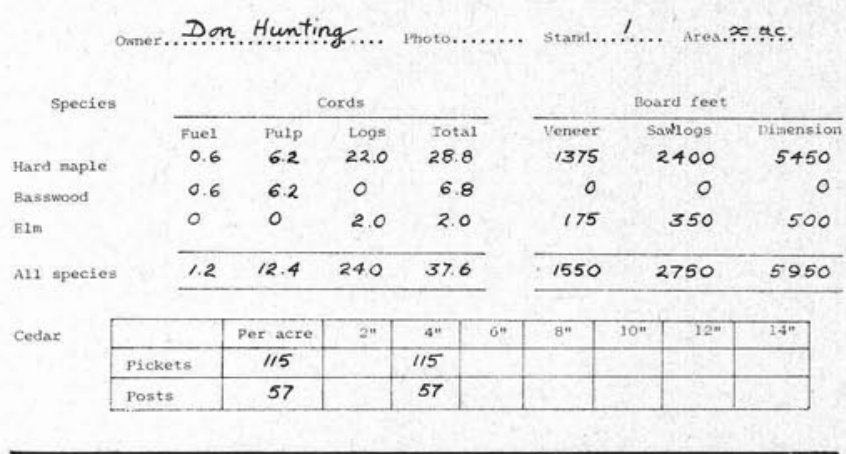

under dimension quality and this includes all three log classes. The sawlog class includes saw- and veneer logs and the veneer class veneer logs only. For hard maple there are 1,375 b.f. of veneer and, by subtraction, 1,025 b.f. of sawlogs, and 3,050 b.f. of dimension stock for a total of 5,450 b.f.

Harvesting of all sawlogs would also yield some cordwood as a by-product. If a conversion factor of two cords per 1,000 b.f. is assumed, then removal of all sawlogs, 5,950 b.f., would yield roughly 12 cords of cordwood - the difference between $2 \times 5.950$ and the 24 cords in sawlog-size trees.

The summary presented here is on a per acre basis but could be readily transformed to a stand basis by multiplication by the area factor. Such a summary might be used if it were possible to introduce dollar values with a view to stand evaluation.

\section{Discussion}

Speed and simplicity are of prime importance where costs are critical, and they usually are on the farm woodlot. Thus, wedge prism analysis has great promise as a means of obtaining reasonable approximations of the basic information needed for assess ment and planning. The method described here has the important added advantages that results are easily understood and many owners could learn to use the method on their own.

Certain weaknesses should be mentioned. Errors in technique could occur in stand delineation or in field sampling. These could be minimized by training, practice and care.

A more serious consideration is the degree to which the man in the field must rely on personal judgment in evaluating tree quality. Again, experience and care would minimize this problem - a problem that would vary in degree from stand to stand.

Finally, it is realized that the conversions are based on general formulae and factors and that this may also introduce errors. But tests and experience indicate that these are not of great importance in the kind of work being done. The method described provides broad inventory information for general management planning or other use and is not relied upon for anything more. Refinements are possible 
and desirable but these would not change the general method.

Flexibility is most useful where stands, owners' objectives, markets and prices are highly variable. Complete field data are recorded with only slightly more effort than is required to walk through the stand. Should additional sample points be desired they may be added to a first sampling without much difficulty. Since the actual recording of data is a small fraction of the total work it is usually advisable to over-sample slightly, but in a situation where only one product was of interest, all trees except those producing it could be ignored.

Although point sampliing theory may be difficult to grasp, the field work can be reduced to a simple routine that anyone can use. Furthermore, routines for different levels of sampling may be set up. Thus the field procedure is highly adaptable. Calculation of estimates and preparation of summaries could

\section{References}

GROSENBAUGH, L. R. 1952. Short cuts for cruisers and scalers. USDA Forest Serv., South. Forest Exp. Sta., Occas. Pap. 126. also be reduced to a routine procedure or, ideally, this phase could be done by computer.

Complete stand summaries have some of the characteristics of a model and provide an excellent basis for presenting and discussing management alternatives. Growing stock can be evaluated and estimates made of what different harvesting operations might produce and what the residual stands would be. Once provided with a set of per acre or per stand summaries for all the stands in his woodlot, an owner can begin to think seriously about what his alternatives are.

Presentation of this kind of a picture often stimulates interest in the woodlot. Owners who are already interested, as well as those who have little or no interest, may both be so affected. The picture, or model, seems to give them the feeling that they now have a basis for planned activity. This is, in essence, the principal objective of the analysis.

WILSON, D. A. and W. C. ROBBINS. 1969. Formulas and tables for point-sampling in forest inventory. Maine Agr. Exp. Sta. Bull. 671.

\section{to a traveller...}

It's the Lord Simcoe ... a friendly welcome... superb service... fine lounges and restaurants... all at sensible prices... and for convenience the subway is right at the door.... in the heart of downtown Toronto. Next time you visit Toronto, enjoy it more than ever... stay at the Lord Simcoe.
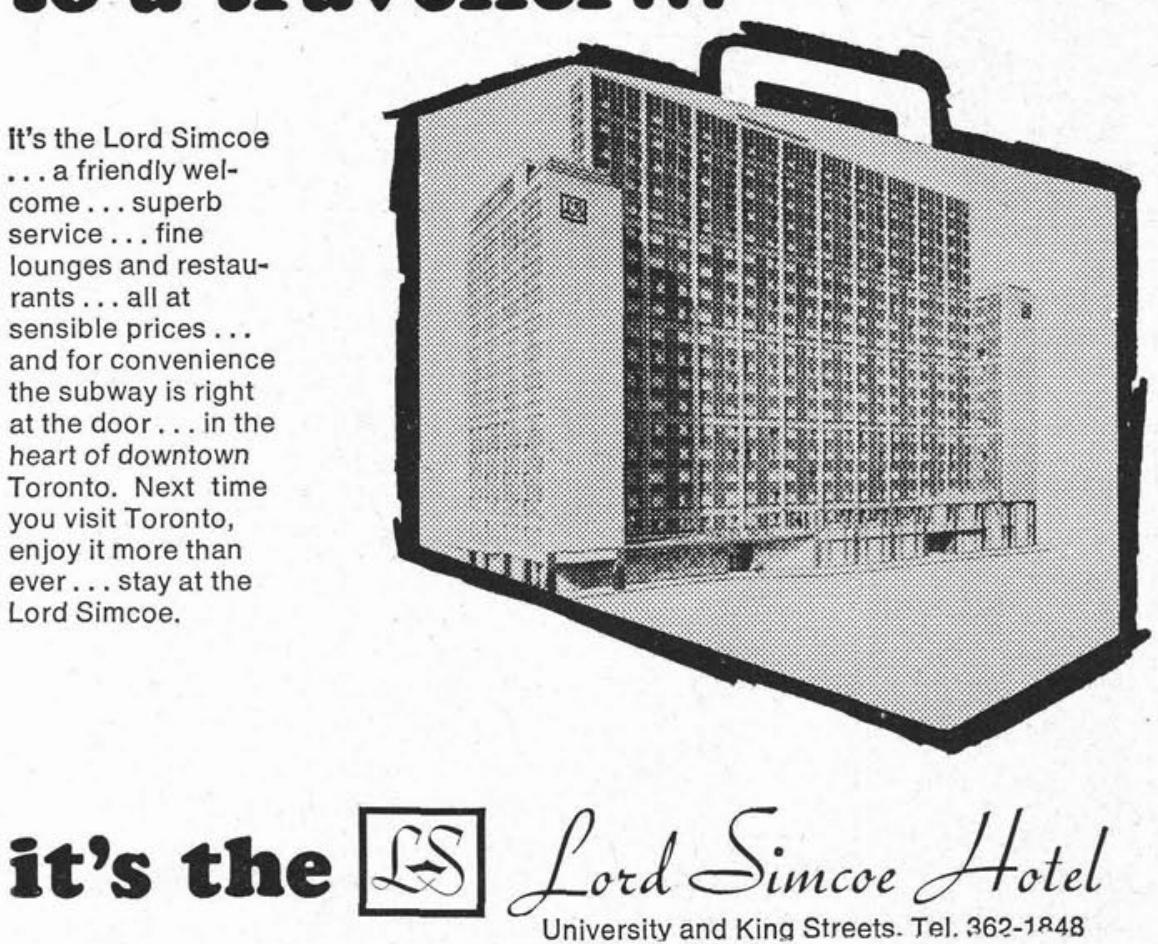